\title{
Milli Eğitim Bakanlığı 2023 Eğitim Vizyonu Belgesi ve Dewey’nin Türkiye Maarifi Hakkında Raporu: Belge Analizi *
}

\section{Educational Vision Document of the Ministry of Education and Dewey's Report on Turkish Education System: Document Analysis}

Seçil Dayıŏlu Öcal ${ }^{a, * *}$, Seher İşcan ${ }^{b}$

a Öğretim Görevlisi Dr., Hacettepe Üniversitesi, Yabancı Diller Yüksekokulu, Beytepe Kampüsü, 06800, Beytepe/ANKARA ORCID: 0000-0002-4165-9317

${ }^{\text {b }}$ Doktor Öğretim Üyesi, Pamukkale Üniversitesi, Yabancı Diller Yüksekokulu, 20070, Kınıklı Yerleşkesi/DENIZLİ ORCID: 0000-0001-6647-3888

\section{MAKALE BİLGISİ}

Makale Geçmişi:

Başvuru tarihi: 31 Ocak 2020

Düzeltme tarihi: 08 Mayıs 2020

Kabul tarihi: 05 Haziran 2020

Anahtar Kelimeler:

Dewey

2023 Eğitim Vizyon Belgesi

Köy Enstitüleri

Öğrenci Merkezli Eğitim

Türkiye Maarifi Hakkında Rapor

\section{ART ICLE INFO}

\section{Article history:}

Received 31 January 2020

Received in revised form 08 May 2020

Accepted 05 June 2020

\section{Keywords:}

Dewey,

2023 Educational Vision Document

Village Institutions

Student-centered Education

The Report on Turkish Education System
ÖZ

Bu çalışmada, Atatürk tarafindan John Dewey’ye hazırlatılan "Türkiye Maarifi Hakkında Rapor" ile Milli Eğitim Bakanlığı tarafindan hazırlanan "2023 Eğitim Vizyonu Belgesi” arasında kullanılan kavramlar açısından benzerlikler ve farklılıklar nitel araştırmanın belge analizi tekniğiyle incelenmiştir. Araştırmacılar belgeleri inceledikten ve ilgili kavramlardan temalara ulaştıktan sonra ana başlıklara ulaşmıştır. Araştırmanın bulgularına göre öğreneni merkeze alan öğrenci odaklı bir yaklaşım, yaparak ve yaşayarak öğrenme ve öğretmen yetiştirme her iki belgenin ortak temaları olarak ortaya çıkmıştır. Dewey'nin raporunda temel eğitim ve eğitimin o yöreye özgü niteliklere sahip olması önemsenmiştir. MEB 2023 Eğitim Vizyonu Belgesi'nde ise teknoloji ve eğitim arasında bağ kurulmuş ve okul yöneticiliğinin meslekleşmesi ön plana çıkmıştır. Bununla birlikte, köy enstitülerinin kurulmasının Dewey'in raporunun en önemli sonucu olduğu düşünülmektedir.

\section{A B S T R A C T}

This study examines the similarities and differences between "The Report on Turkish Education System" administered by John Dewey appointed by Atatürk, and 2023 Educational Vision Document" administered by Ministry of Education via document analysis. After analyzing the documents and identifying the sub-themes, the researchers organized the main themes. According to the findings, 'student-centered education, experiential learning, and teacher education' were the common points. Dewey's report emphasized the basic level of the education and the qualified and locally well-defined instructional processes. "2023 Educational Vision Document" by Ministry of Education indicated that technology and education should be linked and the school administration was proposed as a profession. Considering Dewey's report, "village institutions" were thought to be the apparent result of his report.

\section{Giriş}

Toplumların gerçek ilerlemeler kaydedebilmelerinin zorunlu yolunun eğitimden geçtiği bilinen bir gerçektir.
Eğitimsel problemlerini köklü bir şekilde çözemeyen toplumların çağa ayak uydurmaları ve hayatın diğer alanlarında başarıyı yakalamaları güçtür. Osmanlı Devleti'nin akibeti buna örnek teşkil etmektedir. Osmanlı

*Bu çalışmanın ilk bulguları, 19-22 Haziran 2019 tarihinde Ankara Üniveristesi’nde düzenlenen VI. EJER Kongresi'nde bildiri olarak sunulmuştur.

** Sorumlu yazar/Corresponding author

e-posta: secild@ hacettepe.edu.tr 
Devleti’nin çağın gerektirdiği değişimi ve yenilikleri yakalayamayarak parçalanıp yıkılmasında eğitim kurumlarının yetersizliğinin ve geri kalmışlığının rolünü çok iyi bilen Atatürk, bu sebeple, Cumhuriyetin ilk kuruluş yılllarından itibaren eğitimdeki reformlara öncelik vermiştir. Bunu gerçekleştirmek için yaptıklarından biri de dönemin önde gelen eğitimcisi ve filozofu John Dewey’yi 1924 yılında eğitim sorunlarıyla ve reformlarıyla ilgili olarak Amerika'dan Türkiye'ye özel olarak davet etmesidir (Bülbül, 2009).

John Dewey 1859-1952 yıllarında yaşamış ve felsefeci, eleştirmen ve psikolog olarak Amerikan eğitimini şekillendiren bir güç olmuştur. Eğitimi merkeze alarak topluma ve bireye yönelik çalışmalar yapan Dewey, pragmatizm doğrultusunda, eğitimin uygulamaya dönük ve bireylerin ve toplumların hayatlarını kolaylaştıracak şekilde olması gerektiğini belirtmiş ve ilerlemecilik eğitim felsefesi ile bunun gerçekleşeceğini savunmuştur. Eğitimde özellikle deneyim kavramını merkeze almış, bu kavramı öğrenmeyi sağlayan bir araç olarak nitelendirmiştir. Öğrenme sürecinde öğretmenlerin bireylere deneyim kazanmada rehberlik etmesi gerektiğini vurgulayarak, öğrenme ve öğretme ortamının buna göre düzenlenmesi gerektiğini belirtmiştir (Saylan ve Çiftçioğlu, 2011). Dewey, Faydacı Felsefe'ye dayanan İlerlemecilik, Yeniden Kurmacilık ve Yapılandırmacılık akımlarına temel teşkil eden eğitim felsefesini demokrasi ve demokratik ilkelerle birlikte tartışmıştır. Dewey, faydacılığa dayalı olarak geliştirdiği felsefesini temel alan bir eğitim kuramı oluşturmuş ve özellikle eğitim alanında uygulamaları etkileyen tartışmalar yapmıştır. Eğitim, demokrasi, özgürlük gibi konularda etkili görüşler öne süren Dewey, bu görüşlerini eğitim alanında uygulamaya koyarak okulun eğitim aracılı̆̆ toplumu geliştirme işlevini derinlemesine analiz etmiştir (Selvi, Sönmez ve Özüdoğru, 2014).

Dewey'nin eğitim felsefesi olan 'ilerlemecilik', eğitimin, sürekli var olan gelişme ve değişmelere göre, bireyin çevresiyle etkileşimini devam ettirdiği sürece, kendi deneyimlerinin gelişimi ve yenilenmesini mümkün kılacak şekilde, bilimsel bir mahiyette yapılandırılmasını savunur (Dewey, 1997). Darwin'in Türlerin Kökeni kitabından çok etkilenmiş olan Dewey, her şeyin değiştiğine, hiçbir şeyin aynı kalmadığına inanan bir felsefeyi takip etmiştir. Kısacası, insan için tek gerçek, sürekli değişmeye dayanan yaşantıdır. Bu düşünceye göre, insan çevresiyle etkileşim içinde olan bir varlık olduğundan zihni deneyimleriyle sürekli gelişir. Bu sebepten, eğitim de sürekli değişme ve farklılaşma anlamına gelen doğa yasası tarafindan belirlenmelidir. Sürekli değişmenin sonucunda, son gerçeğe ulaşmak mümkün değildir, zaten öyle bir son gerçek de yoktur (Sönmez, 2008).

Dewey'nin eğitim felsefesinde ağırlıklı olarak göze çarpan iki öğrenme kuramından bahsedilebilir. Bunlardan ilki, yaparak ve yaşayarak öğrenmedir. Kolb'a göre,

Öğrenme sürecinde yaşantı önemli bir yere sahiptir. Yaşantısal ögrenme kuramında düşünceler sabit ve değişmeyen öğeler olmayıp, yaşantılar yoluyla tekrar oluşabilmektedirler. Bu kuramda dört öğrenme biçimi tanımlamıştır. Bunlar, Somut Yaşantı (SY), Yansıtıcı Gözlem (YG), Soyut Kavramsallaștırma (SK) ve Aktif Yaşantı (AY) öğrenme biçimidir. Her öğrenme biçimini temsil eden öğrenme yolu birbirinden farklıdır. Somut Yaşantı için "Hissederek", Yansıtıcı Gözlem için "İzleyerek, Dinleyerek", Soyut Kavramsallaştırma için
"Düşünerek", Aktif Yaşantı için "Yaparak" öğrenme söz konusudur. Yeni bilgiyi almak için, ögrenciler önyargı olmaksızın kendilerini yeni yaşantılara açık tutabilmeli, yaşantıların çeşitli açılardan gözlemlemeli ve yansıtmalı, gözlemlerini mantıklı kuramlar içine oturtabilecek kavramlar oluşturabilmelidirler. $\mathrm{Bu}$ kuramları, karar verme ve problem çözme evrelerinde kullanabilmelidirler (Kolb, 1984, aktaran Mutlu, 2008: 5-6).

Dewey'nin eğitim felsefesine 1şık tutan bir diğer kuram ise Yapılandırmacılık'tır. Yapılandırmacılık genel anlamıyla, ögretmen tarafindan aktarılan bilgiyi almak ve depolamaktan çok öğrencilerin yeni fikirlerini veya yeni öğrendiği kavramları önceki bilgileri üzerine yapılandırdığını savunan bir öğrenme yaklaşımıdır (BenAri, 2001; Hsu, 2004; akt. Balım, İnel ve Evrekli, 2008). Yapılandırmacı öğrenme yaklaşımında, bilgi bireyin dışında değil, kendileri tarafindan yapılandırılır. Öğrenmede bireye bilgiyi aktarmak değil; bilgiyi zihinsel süreçlerden geçirerek yapılandırmak esastır. Diğer bir deyişle, yapılandırıcı öğrenme yaklaşımı, bilginin bireyde halihazırda var olduğunu ve bilginin öğretmenlerin zihninden öğrencilerin zihnine direk olarak transfer edilemeyeceğini öne sürmektedir. Öğrenci kendisine öğretilen bilgiyi deneyimleyerek anlamlandırmaya çalışır (Lorsbach ve Tobin, 1997). Bu kuramda, öğrenci merkezli öğrenme esastır.

Dewey, eğitim felsefesini bilim ve bilimsel yönteme dayandırmaktadır. Bilimsel yöntemin basamaklarını ise şöyle siralar:

1.Güçlük yaratan bir durumla karşı karşıya kalma,

2.Bu durumda problemi keşfedip tanıma,

3.Olası çözümleri belirleme ve denenceler kurma,

4.Denenceleri sınama, sonuçları düşünme,

5.Uygulama sonuçlarına göre denenceleri askıya alma, değiştirme, onarma (Sönmez, 1991; Yıldırım, 1996; akt. Bender, 2005: 17).

Özetle John Dewey’ye göre;

- Okul hayata hazırlık değil, hayatın kendisidir. Deneyimlerin yorumlanması ve yeniden yapılandırılmasıyla gerçekleşir. Çocuk kendi yaşına ve kapasitesine uygun deneyimlerle öğrenmelidir.

- $\quad$ Öğrenme doğrudan çocuğun ilgi alanlarına uygun olmalıdır ama bu tamamen çocuğun isteklerine göre eğitimin oluşturulacağı anlamına gelmez. Çünkü çocuk belirli amaçları koyacak kadar olgun değildir. Öğretmenlerin rehberliğine ve yönlendirmesine ihtiyaç vardır.

- $\quad$ Öğrenme, öğrenenin karşısına çıkacak problemleri çözme yoluyla gerçekleştirilmelidir. Öğrenme, öğretmenin öğrencilerin zihnine bilgileri doldurduğu bir süreç değildir. Pratik bir süreçtir. Öğrenciler yaparak, kendileri deneyimleyerek, kendi başlarına sonuçlara ulaşmalıdır. Ulaştıkları sonuçları test edebilmeli ve eğer işe yaramıyorsa, başa problemin kendisine geri dönmelidirler. Eğitimde bilimsel yöntem bunu gerektirir.

Öğretmenin rolü tavsiyede bulunmak, yardımcı olmaktır. Öğretmen sabırlı olmalı, öğrencinin doğru olanı kendi başına bulmasına izin vermelidir.

Bilgiler öğretilirken, onların mutlak doğrular olmadığı, sadece test edilmiş ve işe yararlılığı kanıtlanmış hipotezler olduğu belirtilmelidir. Aynı şey, toplumsal ve 
ahlaki değerler için de geçerlidir. Doğru olarak kabul edilen şeyin sürekli değişime tabi olduğu unutulmamalıdır.

- Okul rekabeti değil, işbirliğini desteklemelidir. Dewey’ye göre işbirliği ve uyum, rekabet ve kişisel kazançtan daha önemlidir. Kişisel gelişim için, öğrencilerin birbirleriyle işbirliğinin insan doğasına daha uygun olduğuna inanır.

- Demokrasiyi öğretebilmek için, demokratik bir okul gereklidir. Öğrenciler yönetmeye, fikirlerin özgürce tartışılmasına ve tüm eğitsel deneyimlere katılmaya teşvik edilmelidir.

- Yetiştirilmek istenen insanın amaçları bellidir. Başka bir ifadeyle, kişinin gelişimi kendi haline ya da çocuğun isteklerine bırakılmamıştır. Amaç, demokratik, işbirliği yapabilen, içinde bulunduğu toplumla uyumlu bireyler yetiştirmektir. Hedeflerinin kesinliği bakımından, Dewey'nin eğitim felsefesi diğer özgürlükçü eğitim felsefelerinden farklıdır (Ünver, 2016).

John Dewey, yaptığı çalışmalar sonucunda, bakanlığa gözlem ve incelemelerinin sonuçlarını içeren iki rapor hazırlamıştır. Bunlardan ilki, Türkiye'den ayrılmadan önce yazdığı ve bir rapor olmaktan öte eğitim bütçesine acilen konulması gereken bazı ödenekleri gösteren uyarı niteliğinde bir belgedir. Diğeri, John Dewey'nin Amerika'ya döndükten sonra yazıp Türkiye'ye yolladığ 30 sayfadan oluşan Türkiye Maarifi Hakkında Rapor'dur (Dewey, 1924). Dewey'nin Türk Marifi Hakkındaki raporu birey odaklı eğitim kuramlarına dayanmaktadır. Raporun genel felsefesi, bu kuramlardan pragmatizmi desteklemektedir. Pragmatizm, 19. yy sonu ve 20.yy başlarında İngiltere ve Amerika'da ortaya çıkan bir felsefe akımıdır. "Pragma" eski Yunan'da 'eylem' ya da 'hareket tarz1' anlamina gelmektedir. (Sönmez, 2008). Bender'e (2005) göre, Dewey Pragmatist felsefeyi eğitime uygulamıştır. Ona göre; eğitim, yaşam boyu süren bir eylemdir. Bu yüzden en etkili öğrenme, yaparak ve yaşarak edinilir. Çocuğun doğal yapısı, bireysel farklılıkları dikkate alınmalı ve eğitimin merkezi çocuk olmalı, dersler de onun ilgi ve yeteneklerine göre düzenlenmelidir. Çocuk edilgen, ezberci bir eğitime asla zorlanmamalı, kurama değil uygulamaya ağırlık verilmelidir. Bilgiler hiçbir zaman hazır sunulmamalı, çocuğun keşfetmesine ve düşünmesine olanak tanınmalıdır.

Dewey'nin Türk Maarifi Hakkındaki Raporu'nda, John Dewey'nin kurulacak yeni eğitim sistemi hakkındaki önerileri yer almaktadır. Böylelikle rapor, MEB programının yapılandırılmasına büyük katkı sağlamıştır. Efendioğlu, Berkant ve Arslantaş (2010) köy enstitülerinin kuruluş mantığı ve dayanaklarında, bu raporun yansımalarının görülmekte olduğunu belirtmişlerdir çünkü John Dewey'nin (1924) deneyime ve uygulamaya dayalı eğitim-öğretim modelinde çevre ile etkileşim de önemlidir. Raporun 1şığında ülke 21 bölgeye ayrılarak 21 köy enstitüsü kurulmuş ve böylece 21 adet eğitim ve üretim merkezi oluşturulmuştur. Bu okullarda Genel Kültür Dersleri ve Meslek Bilgisi Dersleri yanında Tarım-Ziraat ve Hayvancılık dersleri de iş içinde, yaparak- yaşayarak ve uygulamalı olarak verilmiştir. Ayrıca, dünya klasikleri Türkçe'ye çevrilmiş, köy enstitülerinde okuyan öğrencilerin her ögrretim yılında bunlardan 21 tanesini okuması, tanıtması ve eleştirisini yazması zorunlu kılınmıştır.
Böylece farklı bir okur yazar kitlesi oluşturulmuştur. Okur yazar oranının yükseltilmesine yönelik kütüphane ve kütüphanecilik programı yurt genelinde yaygınlaştırılmaya çalışılmıştır. Örgün eğitim alanında tarım meslek liseleri açılmış, ziraat fakültelerini sayısı arttırılmış, mevcut eğitim programları geliştirilmiş ve şartlara göre güncellenmiştir.

Kösterelioğlu ve Bayar (2014) Türk eğitim sisteminde var olan genel sorunları, öğretmenin mesleki gelişimi ve hizmet içi eğitimi, eğitimde yöneltme/mesleki yönlendirme eksikliği, nitelikli eğitim yöneticisi yetiştirilmesi ve atanmas1, öğretmenin istendik yeterliklere uygun yetiştirilmesi, eğitimde dershaneler sorunu, fiziki alt yapı ve donanım eksiklikleri, eğitim politikalarının ideolojik etkilerin etkisinde kalması, öğretmenlik kariyer basamaklarının sistemde yarattığı düşünülen sorunlar ve eğitim kademeleri arasında geçişlerde sınav odaklı bir eğitim anlayışının yarattığı sorunlar olarak sıralamıştır. Türkiye'de bugüne kadar milli eğitim sistemini geliştirmeye dönük olarak pek çok proje hazırlanmış ve gerçekleştirilmiştir. Ancak, planlar, hedefler, politikalar, ilkeler belirlenip uygulamaya konulmasına rağmen, eğitimde hedeflenen sonuçlara bir türlü ulaşılamamıştır. Milli Eğitim Şuraları'nda alınan kararlar ve 1963'ten günümüze kadar uygulanan beş yıllık kalkınma planlarındaki eğitim hedefleri ve politikaları incelendiğinde, alınan kararların hayata geçirilmesi yönüyle teori ve uygulama paralelliğinin sağlanamadığ görülmektedir (Şener, 2018). John Dewey’nin Türk Eğitim Sisteminin sorunlarıyla ilgili yaptığı tespitlere ve çözüm önerilerine bütüncül olarak bakıldığında; aslında bu sorunların oluşumunun, günümüzde bile, birbirleriyle ilişkili olarak ortaya çıktığı ve bu sorunların da yüzeysel değil, sorunların temeline inen ve çok kapsamlı bir bakış açısıyla ele alındığında çözülebileceği rahatlıkla görülebilir (Bülbül, 2009).

Milli Eğitim Bakanlığı tarafindan hazırlanan Millî Eğitim Bakanı Ziya Selçuk tarafından 23 Ekim 2018 günü kamuoyuna açıklanan MEB 2023 Eğitim Vizyonu Belgesi, yaklaşık 100 yıl önce tespit edilen ve günümüze değin etkili ve kalıcı bir biçimde çözülememiş bu problemlerin çözülmesi için bir rehber ve yol haritası niteliği taşımaktadır. MEB 2023 Eğitim Vizyonu Belgesi’nin temel felsefesi, insanı, eğitimin ana ögesi olarak konumlandırmaktır. 2023 Eğitim Vizyonu'nun en temel felsefi önermesi, insanın ontolojik (varoluşsal) birlik ve bütünlüğü içinde yeniden ele alınması gerektiğidir. Eğitim felsefesinin, ontolojik boyutu kadar epistemolojik (bilgi) boyutu da meseleyi bütünsel olarak ele almak açısından önemlidir. Bilgiyi yalnızca uygulanabilirliği ve işe yaradığı ölçüde doğru kabul eden pragmatizm, varlığın birliğini parçalayarak sadece ontolojiden uzaklaşmakla kalmamakta aynı zamanda epistemolojiyi de kısırlaştırmaktadır. Bilgiyi yalnızca uygulanabilirlik veya fayda sağladığı noktada kullanımda olan bir meta olarak algılayan pragmatizm, insanı modern hayatın gerekleri için bilgi üreten mekanik bir varlığa dönüștürmektedir (Biesta, 2015; Spring, 2017, akt. Baltacı ve Coşkun, 2019). Türk toplumunun bilgiyle olan pragmatik ilişkisini yeniden kurgulaması ve varlıkbilgi dengesini yeniden yapılandırması adına MEB 2023 Eğitim Vizyonu Belgesi'nin öngörüleri kılavuz niteliğindedir. $\mathrm{Bu}$ belgede, insan odaklı eğitim anlayışının ve felsefesinin zirve yaptığı nokta, ontoloji ile epistemoloji birlikteliğini bir ahlak görüşüyle taçlandırma çabasıdır. 
Ayıran, dıșlayan ve indirgeyen bir anlayıș yerine ayırt eden ve birleştiren bir felsefeye uygun bütünsel bir insan yaratma düşüncesi, hedeflenen eğitim için dikkate alınması gereken önemli bir başl1ktır (MEB, 2018). Bununla birlikte Kepes (2018) eğitim sürecinin sadece istatistiki veriler veya mekanik ve iktisadi boyutlarıyla değerlendirmenin yeterli olmayacağını ifade etmiştir. Bu bağlamda eğitimi, mekanik ve salt nicel başarı algısından kurtararak içinde insani değerlerin de olduğu süreç ve sonuç odaklı bütünleşik bir sistem kurgulamayı hedefleyen 2023 Vizyon Belgesi ise eğitimin, genel olarak müfredat odaklı ve pragmatik sonuçları önemseyen yapısının göz ardı edilerek paradigmatik yapıya ulaşması gerçekliğini vurgulamaktadır (MEB, 2018). İlerlemeye dönük, modern ve geleneksel değerleri içselleştirmiş bir birey yetiştirme amacındaki 2023 Eğitim Vizyonu Belgesi'ne göre eğitim, modern eğitim süreçlerinin kısıtlayıcı sınırlarını da aşarak yeni bir felsefi çözümlemeye imkân tanımalıdır. Bu noktada insanı sosyal süreçlerden ayırt eden anlayış reddedilmekte; birey ve toplum birliğine önem veren bütünsel bir insan tasavvuru dikkate alınmaktadır (Baltacı ve Coşkun, 2019). 2023 Eğitim Vizyonu Belgesinin felsefi yaklaşımının bir çeşit bütünleşme düşüncesi taşıdığı aşikadır.

2023 Eğitim Vizyonu Belgesi'nde farklı eğitsel ögelere ve alanlara vurgu yapılmıştır. Düşkün, Arık ve Aydagül'e (2018) göre vizyon belgesinde en önemli vurgu "mutlu çocuklar" kavramı üzerinedir. Belgede çocuğun refahına ve mutluluğuna vurgu yapılarak, çocuğun iyi olma hali yaklaşımı benimsenmiştir. Ayrıca, eğitim sürecinde, sınav baskısının etkili olduğu bir ölçme-değerlendirme ve kademeler arası geçiş sisteminden, çocuğun yapabilirliğini ortaya çıkarıp geliştirmeyi hedefleyen bir sisteme dönüşüm amaçlanmaktadır. $\mathrm{Bu}$ bağlamda, yeterlilik temelli değerlendirme sistemi kurulması, sinavla öğrenci alan okul oranının azaltılması, eşzamanlı olarak tüm okullarda niteliğin arttırılması gibi öğrenme seviyeleri arasındaki uçurumunun kapanması hedefine yönelik adımlar öngörülmektedir. Okulun merkezi önemini vurgulamakla birlikte eğitimi yalnızca okulla sınırlı görmeyen; okul dışı ortamları ve paydaşları da içeren bir yaklaşım söz konusudur. Okulların kendi gereksinimlerini belirleyebilen, bunları gidermek için doğrudan kullanabileceği bir bütçeye, kurumsal kapasiteye ve yetkiye sahip olan güçlü kurumlar haline gelmesi önemli bir ihtiyaçtır. Belgede yer alan, 'Okul Gelişim Planı' çerçevesinde her okula bütçe verilmesi hedefi okullara güçlenme olanağı tanıyacaktır. Müfredatı ve öğrenme ortamını çocukların farklılıklarına göre düzenleyen öğretmen, iradesi gelişmiş, doğal merakını koruyan ve öğrenmenin kendisini bir ödül olarak gören öğrenciler yetiştirmeyi hedeflemektedir. Belgede, ancak 'Öğretmenlik Meslek Kanunu' ile öğretmenliğin özel bir statüye kavuşabileceği; bu sayede çalışma koşullarının iyileştirilmesinin daha kolay hale geleceği belirtilmiştir. MEB 2023 Eğitim Vizyonu Belgesi'nin bir diğer hedefi de, okullarda tasarım-beceri atölyelerinin kurulması yoluyla öğrencilere yaparak ve yaşayarak öğrenmeleri için firsat tanımaktır. Ayrıca, çocukların zihinsel, sözel ve sosyalduygusal gelişimlerinde önemli rol oynayan okul öncesi eğitimin en az bir yıl zorunlu ve ücretsiz olmasının belirlenmesi, uzun zamandır beklenen bir gelişmedir. $\mathrm{Bu}$ bağlamda, beş yaş için erken çocukluk eğitiminin 2020'de ülke genelinde zorunlu hale gelmesi amaçlanmaktadır. Tüm bu hedefler, eğitim sisteminin dönüşümü için kritiktir.
Hedeflere ulaşmak için öncelikle veriye dayalı bir hazırlık ve geliştirme sürecinden geçilmesi, ardından küçük ve orta ölçekli pilot uygulamaların yapılması kararı, etkili, uygulanabilir ve sürdürülebilir bir plan için önemli olacaktır.

Dewey felsefesi ile örtüşen, öğretmenin yönetmediği, gütmediği; rehberlik ve ustalığını konuşturduğu bir temel politika belirleyen felsefeye göre temel becerilere ilişkin zorunlu derslerin korunması şartıyla, zorunlu ders saat ve çeşitleri azaltılarak, derinleşmeye, kişiselleştirmeye ve uygulamaya zaman ayrılacaktır. Ayrıca programlar, tüm kademelerde bütüncül, yetenek kümeleriyle ilişkilendirilmiş, esnek ve modüler yapılar olarak yapılandırılacaktır. Çocukların öğrenmesiyle ilgili tüm aktörlerin okulu iyileştirme çalışmalarında yer aldığı "Okul Gelişim Modeli” kurulacak, ülke genelinde yönetim ve öğrenme etkinliklerinin izlenmesi, değerlendirilmesi ve geliştirilmesi için okul bazında "Veriye Dayalı Planlama ve Yönetim Sistemi"ne geçilecektir. Eğitimde ölçme ve değerlendirme kapsamında, öğrencilerin her ders ve düzeyde yeterliliklerinin belirlenmesi, izlenmesi ve desteklenmesi için "Yeterlilik Temelli Değerlendirme Sitemi" kurulması ve okul ve öğrenme ekosistemindeki iyileşmeler doğrultusunda sınavla öğrenci alan okulların sayısının kademeli olarak azaltılması planlanmıştır (MEB, 2018).

Öğretmen yetiştirme ve şartlarının iyileştirilmesi konusunda da MEB 2023 Eğitim Vizyonu Belgesi'nde tedbirler alındığı anlaşılmaktadır. Vizyon planında, ihtiyaç duyulan ölçütleri taşıyan eğitim fakültelerinde, özgün bir yapılanmayla uygulama ağırlıklı öğretmen yetiştirme programlarının düzenlenmesi, öğretmenlerin mesleki gelişimlerinin lisansüstü düzeyde desteklenmesi ve bir yan dal sahibi olması, ücretli öğretmenlerin ücretlerinin iyileştirilmesi ve "Öğretmenlik Meslek Kanunu" çıkarılmasına yönelik hazırlık çalışmalarının yürütülmesine dair maddeler yer almaktadır. Ayrıca, okul yöneticiliğinin yüksek lisans düzeyinde mesleki uzmanlık becerisine dayalı profesyonel bir kariyer alanı olarak yapılandırılması ve okul yöneticilerinin özlük haklarının iyileştirilmesi planlanmaktadır. Cumhuriyet'in ilanı ile yeniden yapılandırılan eğitim kurumlarının hâlâ çözülemeyen problemlerinden biri olan eğitime ayrılan bütçenin yetersizliği konusunda, Millî Eğitim Bakanlığının diğer bakanlıklarla yapacağı iş birlikleri ve projelerle kaynak oluşturması ve eğitime yapılan hayırsever bağışlarının daha etkili yönetilmesi için iller ve bakanlık düzeyinde bir yapı kurulması ile bir çözüme ulaşılması hedeflenmektedir (MEB, 2018).

Özetle, Dewey’nin raporu o dönemde kuruluş aşamasındaki Cumhuriyetimizin eğitim süreçlerinin yapılandırılmasına ilişkin önerileri içermektedir. MEB 2023 Eğitim Vizyonu Belgesi'nde de Cumhuriyetimizi 100. yılına taşıyacak eğitim süreçlerinin hedefleri yer almaktadır. Bu bağlamda, ilgili alan yazın tarandığında, her iki belgeyi de ele alan bir çalışmaya rastlanmamıştır. 1924 Türkiyesi'nde eğitim alanında konulan hedeflere ne kadar ulaşılabildiği ile bu hedeflerle 2023 eğitim hedeflerinin örtüşüp örtüşmediğinin 
saptanması açısından bu çalışmanın önemli olduğu düşünülmektedir. $\mathrm{Bu}$ bakımdan bu araştırmada aşağıda verilen sorulara cevap aranmıştır:

- John Dewey'e hazırlatılan Türkiye Maarifi Hakkında Rapor'da kullanılan temalar nelerdir?

- MEB 2023 Eğitim Vizyonu Belgesi'nde kullanılan temalar nelerdir?

- Türkiye Maarifi Hakkında Rapor'da ve MEB 2023 Eğitim Vizyonu Belgesi'nde kullanılan temalar arasında benzerlikler nelerdir?

- Türkiye Maarifi Hakkında Rapor'da 2023 Eğitim Vizyonu Belgesi'nde ve MEB temalar arasında farklılıklar nelerdir?

\section{Yöntem}

$\mathrm{Bu}$ araştırmanın yöntemiyle ilgili detaylı bilgiler alt başlıklarda yer almaktadır.

\subsection{Araştırma Deseni}

$\mathrm{Bu}$ çalışmada, nitel araştırmalarda yaygın kullanılan veri toplama yöntemlerinden biri olan belge incelemesi kullanılmıştır. $\mathrm{Bu}$ yöntem, araştırma yapılan belirli bir konuyla ilgili belgelerin, sistematik biçimde incelenerek yorumlanmasına dayanmaktadır (Bowen, 2009; Yildırım ve Şimşek, 2006). Belge inceleme yoluyla veri toplama yönteminde, ilgili belgeler, içerik çözümlemesiyle kodlanmakta ve kodlar daha sonra ilgili temalar çerçevesinde toplanmaktadır. Buna dayalı olarak, bu araştırmada MEB tarafından yayımlanan "2023 Eğitim Vizyonu Belgesi” ve John Dewey'e hazırlatılan “Türkiye Maarifi Hakkında Rapor" belge incelemesi yöntemiyle incelenmiştir.

\subsection{Araştırmanın Belgeleri}

Araştırma kapsamında MEB (2018) tarafindan yayımlanan "2023 Eğitim Vizyonu Belgesi" ve Atatürk'ün Cumhuriyetimizin ilk yıllarında Türkiye'ye davet ettiği eğitimci John Dewey (1924) tarafindan hazırlanan "Türk Maarifi Hakkında Rapor” incelenmektedir. MEB tarafindan yayımlanan "2023 Eğitim Vizyonu Belgesi" Cumhuriyetin 100. yılına ilişkin eğitim hedeflerini içerdiğinden, John Dewey tarafindan hazırlanan raporda, yeni kurulan Türkiye Cumhuriyeti'nin eğitim sürecine bir yol haritası belirlediğinden dolayı araştırılmaya değer görülmüştür. $\mathrm{Bu}$ iki belgenin yazıldıkları sosyo-kültürel ve politik ortam açısından farklılık gösterdiği gerçeği araştırmacılar tarafından dikkate alınmıştır.

MEB 2023 Eğitim Vizyonu Belgesi, 23 Ekim 2018 tarihinde MEB'in internet sayfasından kamuoyuyla paylaşılmıştır. Bu belgeyle 2023 yılında yüz yaşına girecek Türkiye Cumhuriyeti'nin eğitim hedefleri 140 sayfalık bir açıklamayla ifade edilmiştir. Türk Eğitim Sistemi, temel eğitimden lise eğitimine, farklı okul türlerine ve okulların yönetimsel boyutlarına kadar 20 alt başlık altında oldukça detaylı bir şekilde incelenmiştir. $\mathrm{Bu}$ alt başlıklar şöyle siralanmaktadir:

- $\quad$ Temel Politikamız

- İçerik ve Uygulama

- Okul Gelişim Modeli

- Öğrenme Analitiği Araçlarıyla Veriye Dayalı Yönetim

- Ölçme ve Değerlendirme

- İnsan Kaynaklarının Geliştirilmesi ve Yönetimi

- Okulların Finansmanı

- Teftiş ve Kurumsal Rehberlik Hizmetleri

- Rehberlik ve Psikolojik Danişmanlık

- Özel Eğitim

- Özel Yetenek

- Yabanci Dil Eğitimi

- Öğrenme Süreçlerinde Dijital İçerik ve Beceri Destekli Dönüşüm

- Erken Çocukluk

- Temel Eğitim

- Ortaöğretim

- Fen ve Sosyal Bilimler Liseleri

- İmam Hatip Ortaokulları ve Liseleri

- Mesleki ve Teknik Eğitim

- $\quad$ Özel Öğretim (Milli Eğitim Bakanlığı, 2018).

Dewey 'nin “Türkiye Maarifi Hakkında Rapor" belgesi 1939 İstanbul Devlet Basımevi tarafindan yayımlanan TBMM Kütüphanesindeki orijinal yazılı halinin dijital versiyonudur. Temmuz 1924 yılında Türkiye'ye gelen John Dewey 2 ay süreyle İstanbul'da ve Ankara'da bazı incelemelerde bulunmuştur (Ata, 2001). Bu süreçte edindiği gözlemleri 38 sayfada raporlaştırdığı araştırmaya konu olan belge, yeni Türkiye Cumhuriyeti'nin eğitim politikaları açısından önemli olmuştur. Burada girişin dişında "Program, Maarif Vekilliği Teşkilat,, Muallimlerin Yetiştirilmesi ve Terfihi, Muallimlerin Yetiştirilmesi, Mektep Sistemi, Sihhat ve Hifzıssıhha, Mektep İnzibatı, ve Muhtelif Mevat" şeklinde başlıklar yer almaktadır (Dewey, 1924).

\subsection{Veri Çözümleme}

Araştırmada kullanılan belge incelemesi yöntemi için O'Leary (2014) tarafından önerilen sekiz basamaklı bir belge inceleme süreci takip edilmiştir. Buna göre, birinci aşama, gerekli belgelerin edinilmesini kapsamaktadır. Belgeler, resmi internet sitelerinden edinilmiştir. "MEB 2023 Eğitim Vizyonu Belgesi” Milli Eğitim Bakanlığının resmi internet sayfasından, Dewey'nin yazdığı "Türkiye Maarifi Hakkında Rapor" ise TBMM internet sayfasında açık erişimde olan belgelerden (www.acikerisim.tbmm.org.tr) indirilmiştir. Belgelerin incelenmesinde kullanılacak araştırma sorusu kapsamında olası kodlar ve temalar düzenlenerek referans alınmıştır. 
Böylece ikinci ve üçüncü adımlar tamamlanmıştır. Sonraki adımlarda, ilgili belgelerin kendine ait özellikleri ve hazırlanma süreci hakkında inceleme yapılmış ve “Araştırma Belgeleri” başlığı altında açıklanmıştır. İçerik analizi yoluyla araştırma sorusu çerçevesinde belgelerdeki benzerlik ve farklılıklar düzenlenmiştir.

İçerik analizinde, kodlama yapmak için, araştırmacılar öncelikle belgeler üzerinde eğitime ilişkin kavramlardan ve bu kavramları açıklayan betimlemelerden yararlanır. Belgelerdeki kavramlar birleştirilerek kodlara ve temalara dönüştürülür (Silverman, 2014). Örneğin, bu çalışmada "öğrenci ihtiyaçları, bireysel farklılıklar, gereksinim” gibi kavramlar "öğrenci odaklılık" adı altında bir temada toplanmıştır.

“MEB 2023 Eğitim Vizyonu Belgesi (2018)" ve "Türkiye Maarifi Hakkında Rapor (1924)" belgeleri bu araştırmayı yürüten iki araştırmacı tarafından ayrı ayrı kodlanmıştır. Kodlamada araştırmacılar, öncelikle anahtar sözcükleri ele almış ve sonrasında bu sözcükler karşılaştırılarak kodlar ve temalar ortaya konulmuştur.

Kodlayıcılar arası güvenirlik için, her iki araştırmacının belirlediği toplam kod sayısı (N) 117, uzlaşılan kod sayısı (n) ise 89'dur. Uzlaşı sağlanmayan kod sayısı 28'dir. Güvenirlik katsayısı 0,76 çıkmıştır. Araştırmacıların belirlediği her iki belge için ayrı tablolarda toplanmıştır. $\mathrm{Bu}$ tablolarda her iki araştımacının aynı temaya yönelik belirledikleri kodların frekansı, ilgili temanın toplamına bağlı olarak yüzdeliği verilmiştir (Bkz. EK 1- TABLO 2 ve EK 2-TABLO 3).

\section{Bulgular ve Yorum}

Araștırmanın birinci alt problemi “John Dewey’ye hazırlatılan Türkiye Maarifi Hakkında Rapor'da kullanılan temalar nelerdir?" olarak belirlemiştir. İlgili alt probleme yanıt bulabilmek amacı ile rapor incelenmiş ve Dewey tarafından hazırlanan "Türkiye Maarifi Hakkında Rapor"da şu temalara ulaşılmıştır (EK TABLO 2):

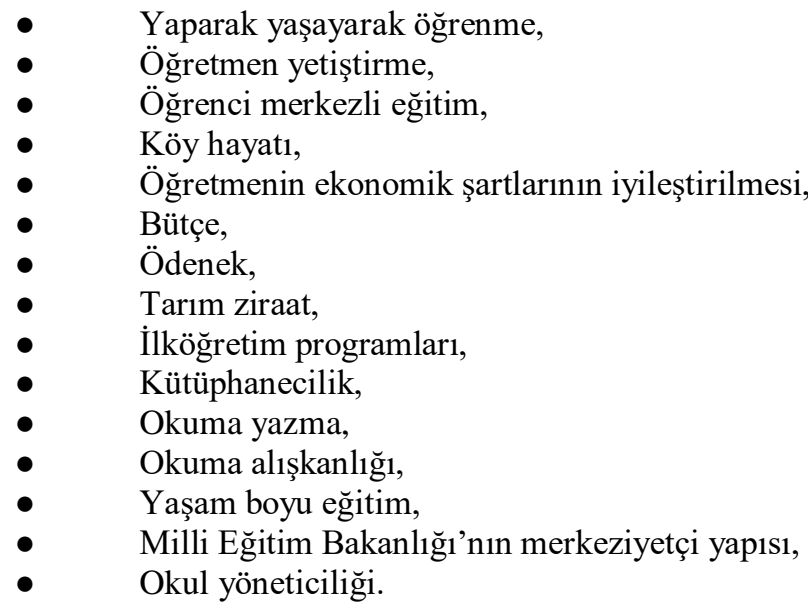

Araştırmanın ikinci alt problemi "MEB 2023 Eğitim Vizyonu Belgesi'nde kullanılan temalar nelerdir?" olarak belirlemiştir. İlgili alt probleme yanıt bulabilmek amacı ile belge incelenmiş ve MEB 2023 Eğitim Vizyonu Belgesi'nde (2018) aşağıdaki temalara ulaşılmıştır (EK TABLO 3):

- Yaparak yaşayarak öğrenme,

- Bireysel potansiyelin gerçekleştirilmesi,

- $\quad$ Öğrenci odaklı eğitim,

- Düşünme becerilerinin geliştirilmesi,

- Öğretmen yetiştirme ve öğretmenin güçlendirilmesi,

- MEB Teşkilatının yeniden yapılandırılması,

- $\quad$ Okul yöneticiliği,

- Yaşam boyu eğitim,

- $\quad$ Eğitimin teknolojiye dayalı olarak dönüştürülmesi.

Araştırmanın üçüncü alt problemi “Türkiye Maarifi Hakkında Rapor'da ve MEB 2023 Eğitim Vizyonu Belgesi'nde kullanılan temalar arasında benzerlikler nelerdir?" olarak belirlenmiştir.

Her iki belge üzerinde yapılan çalışma 1şı̆̆ında beş adet ortak tema saptanmıştır. $\mathrm{Bu}$ temalar ve ilgili belgelerdeki ağırlıkları Tablo 1'de verilmiştir:

Tablo 1. Dewey’nin Türk Maarifi Raporu ve 2023 Eğitim Vizyonu Belgesi'ndeki Ortak Temalar ve Ağırlıkları

\begin{tabular}{lcc}
\hline Temalar & $\begin{array}{c}\text { Dewey'nin } \\
\text { Türkiye } \\
\text { Maarifi } \\
\text { Raporunda } \\
\text { Temanın } \\
\text { Ăğı̆lı̆ı (\%) }\end{array}$ & $\begin{array}{c}\text { MEB 2023 } \\
\text { Ĕgitim Vizyonu } \\
\text { Belgesi } \\
\text { Temanın } \\
\text { A ğırlığı (\%) }\end{array}$ \\
\hline Yaparak Yaşayarak Öğrenme & 9 & 14 \\
Öğrenci Merkezli Eğitim & 5 & 7 \\
Öğretmen Yetiştirme & 7 & 11 \\
Okul Yöneticiliği & 7 & 16 \\
MEB Teşkilatı & 24 & 10 \\
Yaşamboyu Eğitim & 8 & 7 \\
\hline
\end{tabular}

Her iki belgede de ortak olan kavramlardan ilki "yaparak yaşayarak öğrenme"dir. Burada dikkati çeken husus, Dewey'nin (1924) bu kavramdan eğitim alanında ilk kez bahsetmiş olmasıdır. Türkiye Maarifi Hakkında Rapor'da da "yaparak yaşayarak öğrenme" tema ağırlığı olarak \% 9 düzeyinde açıklanmıştır. Bununla ilgili aşağıdaki açıklama yer almaktadir:

Mekteplerin yalnız talebeye bazı ders mevzularını öğretmesi kâfi değildir. Mektepler, cemaat hayatının merkezini teşkil etmelidir. Mektepler, bulundukları yerlerin sıhhî merkezi olmalı, orada sihhati umumiyeye, sari hastalıklara, malarya ve bu hastalıklarla mücadeleye ait bahisler yalnız talebeye öğretilmekle kalmamalı, bütün köy halkına tamim edilmelidir (s. 8-9).

Burada yer alan "yalnız talebeye bazı ders mevzularını öğretmesi kâfi değildir. Mektepler, cemaat hayatının merkezini teşkil etmelidir" ifadesi okulların bulundukları çevreyle ilişkili olması gerektiğini ve bunun da öğrencilerin deneyime dayalı öğrenmelerini desteklediği görülmektedir.

MEB 2023 Eğitim Vizyonu Belgesi’nde (2018) temalardan 118 tanesinin yaparak yaşayarak öğrenmeye yönelik olduğu 
görülmüştür. "Yaparak yaşayarak öğrenme” kavramı, aşağıdaki alıntıda en açık şekliyle yer almıştır:

\begin{abstract}
Eğitim kurumunun temel çıkış noktası, bireyin kendini bilmesini ve tanımasını sağlamaktır. Çocuklar, ebeveynler ve öğretmenler, kendilerini ve çevrelerindekileri tanıdıklarında, birlikte gelişme imkânı doğacaktır. Öğretmen ve diğer yetişkinler, bilgi transferi yerine hissetme, düşünme ve yapmayı tetikleyen yöntemlerle rehberlik ettiği sürece doğal öğrenme ekosistemi korunur. Öğretmen yönetmez, gütmez; rehberlik ve ustalığını konuşturur. Tüm çocukları, öğrenme topluluğunun saygın birer ferdi olarak görür (s. 21).
\end{abstract}

Burada geçen "bireyin kendini bilmesi ve tanıması", "öğretmenlerin hissetme, düşünme ve yapmayı tetikleyen yöntemlerle rehberlik etmeleri” ve "doğal öğrenme ekosistemi" ifadeleri, sınıftaki öğrenme ortamının öğrenciyi merkeze alacak şekilde kurulmasını öngörmektedir.Bu kavramlar "öğrenci odaklı eğitim”e işaret etmektedir ve bu kapsamda Türkiye Maarifi Hakkında Rapor'da (1924) tema ağırlığı \%5 ve MEB 2023 Eğitim Vizyonu Belgesi'nde (2018) ise \%7 tema ağırlığında gözlenmiştir.

“Öğretmen yetiștirme ve hizmet içi eğitim” kavramı ise yine ortak kavramlardan bir diğeridir. John Dewey'nin (1924) “Türkiye Maarifi Hakkında Raporu”nda tema ağırlığı \%7 olarak bulunmuştur. Özellikle öğretmenlerin alanlarına ilişkin yabancı ülkelere gönderilerek hizmetiçi eğitim almaları vurgulanmıştır:

\begin{abstract}
Hizmette bulunan muallimleri yükseltmek için diğer en mühim amil de onların tetkiki için ecnebi memleketlerine gönderilmesidir. Bunun için birkaç senelik muayyen ve müstakar bir program tertip etmeli ve bu program mucibince her sene bir kısım muallimleri muhtelif meseleleri tetkik için harice göndermelidir (s. 21)
\end{abstract}

Bu kavram, MEB 2023 Eğitim Vizyonu Belgesi'nde (2018:41) ise "Mesleki yeterlilikleri yüksek, başarılı öğretmenler, bilgi ve deneyimlerini artırmaları için yurt dışına gönderilecektir" şeklinde belirtilmiştir. Bu belgede tema ağırlığ $1 \% 11$ olarak gözlenmiştir.

Okul yöneticileri ve yöneticiliği de her iki belgede yer alan diğer bir temadır. John Dewey'nin (1924: 18) Türkiye Maarifi Hakkında Raporu' nda "Mektep müdürleri, eğer bugün uhdelerindeki ufak tefek teferruata ait işlerden kurtarılır ve para sarfi hakkındaki usuller değiştirilirse onların vaziyeti çok daha faideli ve çok daha şerefli bir şekle girer." yer almaktadır Bu temanın gözlenme ağırlığı $\% 7$ 'dir. Burada özellikle müdürlerin okulun politika ve liderliği alanlarında etkin olmalarından bahsedilmektedir. Ayrıca, okul yönetici ve memurlarının çalışma şartlarının, öğretmenlerden daha kötü olduğundan ve bu durumun onları meslekten uzaklaştırdığından bahsedilmektedir:

\footnotetext{
Bugün Türkiye'de muallimlerin vaziyeti idare memurları, mektep müdür ve muavinlerininkinden daha iyidir, idare memurları, mevkilerinde çok ani ve lüzumundan fazla tebeddülata maruz kallyorlar. Bunun neticesinden de meslek, manen mutazarrır oluyor (Dewey, 1924: 2).
}

MEB 2023 Eğitim Vizyonu Belgesi’nde (2018:42) ise okul yöneticiliği "profesyonel meslek" ve "kariyer basamağı" ifadeleriyle desteklenirken kişilerin özlük haklarında da iyileştirme öngörülmüştür. "Kariyer basamağı" ifadesi, yöneticilerin yüksek lisans derecesine bağlı olarak uzmanlık alanını öngörmektedir. Yirmi birinci yüzyıl becerileri ve gelişmeler düşünüldüğünde, bu yönlendirme önem taşımaktadır. Temanın gözlenme ağırlığı \%16'dır.

Son olarak her iki belgede de dikkat çeken tema "MEB teşkilatı"dır. Bu konu, John Dewey'nin Türkiye Maarifi Hakkında Raporu'nda aşağıdaki şekilde yer almaktadır:

Diğer taraftan Maarif Vekilliğinin lüzumundan fazla bir
merkeziyet faaliyetine kapılmasında mahallî alâkaları ve mahallî
teşebbüsleri boğması, mahallî idarelerin yapabilecekleri şeyleri
yapmalarına mâni olması ve şehir, köy, sahil gibi muhtelif
sahaların, muhtelif en muzeçte köy mıntakalarının, muhtelif
muhitlerin, çobanlık, hububatçılık, pamukçuluk, meyvacılık...
ilâh. gibi muhtelif sanatların ihtiyaçlarına tetabuk edecek
derecede elastikiyeti haiz olmayan lüzumundan fazla yeknasak bir
maarif teşkilâtı vücuda gelmesi tehlikesi vardır (s. 13).

Burada özellikle merkeziyetçi yapının, yerel özelliklerin farkında olmaması nedeniyle gerekli değişikliği sağlayamamasından bahsedilmektedir. $\mathrm{Bu}$ durum, Dewey'nin eğitim yaklaşımındaki öğrenme ortamının çevreyle olan etkileşiminin öneminin bu rapora yansıması olarak görülmektedir. Bu temanın gözlenme ağırlı̆̆ $\% 24$ 'le en yüksek ağırlıktadır.

MEB 2023 Eğitim Vizyonu Belgesi (2018) dikkate alındığında ise MEB'in gelecekteki öncü rolü üzerinde durulmaktadir:

Millî Eğitim Bakanlığının yeni dönemde oynayacağı rol, talim ve terbiyeyi, Türk milletinin toplumsal bütünleşmesinin ve ortak ülküye dayalı, şimdi ve gelecek tasavvurunun inşasına öncülük etmektir (s. 8).

Buradaki gözlemlenme ağırlığı \%10’dur. Milli Eğitim Bakanlığı teşkilatının, Dewey'nin raporunda yeni kurulan ülke Türkiye Cumhuriyeti'ndeki şekillendirici rolü, 21 . yüzyılda da öncülük yaparak devam ettirmektedir.

Yaşamboyu eğitim her iki belgede yer alan son ortak kavramdır. Türkiye Maarifi Hakkında Rapor'da (1924) tema ağırlığı \%8 ve MEB 2023 Eğitim Vizyonu Belgesi'nde (2018) ise \%7 tema ağırlığında gözlenmiştir. Dewey'nin Türkiye Maarifi Hakkında Rapor'unda yaşamboyu eğitim özellikle sağlık, tarım ziraat gibi konularda okulların yaşa gruplarındaki çocukalara değil aynı zamanda o bölge halkını eğitimesi üzerinde yğunlaşmıştır. MEB 2023 Eğitm vizyon belgesinde ise hızla değişen yaşam koşullarına uyumlandırma olarak karşımıza çıkmaktadır.

Araştırmanın dördüncü ve son alt probleminde, "Türkiye Maarifi Hakkında Rapor'da ve MEB 2023 Eğitim Vizyonu Belgesi'nde kullanılan temalar arasında farklılıklar nelerdir?" sorusuna cevap aranmıştır. Her iki belgedeki temalar karşılaştırıldığında birinde yer alan fakat diğer belgede olmayan kavramlar gruplandırılmıştır.

Dewey’nin (1924) Türkiye Maarifi Hakkındaki Raporu'nda yer alan "köy hayatı" ve bunun güçlendirilmesi daha sonrasında Türkiye'ye özgü model olarak hayata geçirilen "köy enstitüleri”nin kurulması için bir alt yapı olmuştur. Sonraki yıllarda Dewey bu durumu "hayalimdeki okullar 
Türkiye Cumhuriyeti'nde hayata geçirildi" diyerek belirtecektir. Özellikle bulundukları bölgenin özelliklerine göre eğitim veren bu kurumlarda hem akademik hem de sanat ve spor alanlarında gereken insan gücü yetiştirilecektir.

Dewey'nin (1924) Türkiye Maarifi Hakkındaki Raporu'nda, eğitim sistemi genel olarak ele alınmıştır. Ayrıca, ilgili raporda yeni kurulmuş Türkiye Cumhuriyeti'nin koşullarında okuma-yazma bilen ve temel becerilere sahip insan gücü oldukça sınırlı olduğu için ilköğretim daha çok vurgulanmaktadır. Diğer kademelere geçiş yapabilmek için temel eğitimin önemi buradan da anlaşılmaktadır. Bu, henüz emekleme aşamasındaki 1923 Türkiye'si için oldukça anlaşılır bir durumdur.

Dewey (1924) tarafindan öğretmenliğin meslekleşme sürecinin de bu raporda vurgulandığını göze çarpmaktadır. Özellikle ortaöğretimin ardından meslek yüksekokulları aracılığı ile öğretmenlerin eğitim alması ve sürecin hizmetiçi eğitimle de desteklenmesi raporun vurgulanan boyutudur. Gelecek nesilleri yetiştirecek öğretmenlerin eğitimleri oldukça önemsenmiş ve öğretmenlerin, yurt dışına hizmetiçi eğitim için gönderilmesi üzerinde durulmuştur.

MEB 2023 Eğitim Vizyonu Belgesi'nde (2018) ise 21.yüzyıl becerilerine göndermeler yer almaktadır. $\mathrm{Bu}$ beceriler, teknolojiyi etkin kullanmaktan interdisipliner bir yaklaşımla öğrencilerin farklı disiplinleri bilmesine, yaratıcılıktan girşimciliğe kadar farklı boyutları içermektedir. Dolayısıyla, ilgili belgede, teknoloji ve eğitim arasında bağ kurulmuştur. Ayrıca, teknolojinin mutlaka eğitim süreciyle birleştirilmesi söz konusudur. Her öğrencinin kendi yetenek ve becerisiyle ilişkili olarak bireyselleştirilmiş eğitim kavramı ön plana çıkmaktadır. Belgede, okul öncesinden ortaöğretime kadar tüm eğitim kademeleri ve meslek lisesinden sosyal bilimlere kadar tüm okul türleri ele alınmıştır. Öğretmen yetiştirmede Dewey'nin raporuyla karşılaştırıldığında ortaöğretimden sonra yüksekokul eğitiminden 21. yüzyılda lisansüstü eğitimi alması hedeflenerek tamamlanmıştır. İçnde bulunduğumuz çağın koşulları ve bilginin niteliğinin hızla değişmesi nedeniyle bu farklılıkların MEB 2023 Eğitim Vizyonu Belgesi'nde (2018) yer alması 100. yılına yaklaşan Cumhuriyetimiz için bir gereksinimdir.

\section{Tartışma, Sonuç ve Öneriler}

Araştırma kapsamında değerlendirilen her iki belge, Türk Eğitim Sistemi'nin dayandığı eğitim politikaları açısından kritik bir öneme sahiptir. Dewey'nin (1924) raporu genç cumhuriyetimizin başlangıcındaki eğitim sisteminin kurulmasında öncülük etmişken, MEB 2023 Eğitim Vizyonu Belgesi (2018) ise Cumhuriyetin 100. yılı için hedef koymaktadır.

Elde edilen ilk sonuçlar, her iki belgenin dayandığı eğitim felsefelerinin benzerliklerini ve de farklılıklarını böylece ortaya koymaktadır. Dewey'nin Türk Marifi Hakkındaki Raporu birey odaklı eğitim kuramlarından pragmatizmi (faydacılık) desteklemektedir. Pragmatik felsefeye göre, eğitimin merkezi öğrencidir ve yaparak ve yaşayarak öğrenme en etkili öğrenme biçimidir. Bu sebeple, eğitimde kurama değil uygulamaya ağırlık verilmelidir. MEB 2023 Eğitim Vizyonu Belgesi'nin temel felsefesi de insanı eğitimin ana ögesi olarak konumlandırmaktır. 2023 Eğitim Vizyonu Belgesi pragmatik yaklaşımdan bir adım öteye giderek bireyin ontolojik (varoluşsal) birlik ve sosyal bütünlüğü içinde yeniden ele alınması gerektiğini savunmaktadır (Elçiçek ve Han, 2018; MEB, 2018). Belgeye göre, bilgi yalnızca uygulanabilirlik veya fayda sağladığı mekanik durumlar için gerekli olmamalı; birey bütünleşik bir ortamda yaparak ve yaşayarak edindiği tecrübeler 1şığında bilgiyi de üretebilmelidir.

John Dewey'ye hazırlatılan Türkiye Maarifi Hakkında Rapor'da kullanılan temaların bulunması araştırmanın birinci alt problemini oluşturmaktadır. Yapılan belge analizi sonucunda yaparak yaşayarak öğrenme, öğretmen yetiştirme, öğrenci merkezli eğitim, köy hayatının önemi ve öğretmenin ekonomik şartlarının iyileştirilmesi gibi temalara ulaşılmıştır. MEB 2023 Eğitim Vizyonu Belgesi'nde kullanılan temalara ilişkin alt probleme yanıt olarak da ilgili belgede, yaparak yaşayarak öğrenme, bireysel potansiyelin gerçekleştirilmesi, öğrenci odaklı eğitim, düşünme becerilerinin geliştirilmesi ve öğretmen yetiştirme ve öğretmenin güçlendirilmesi gibi temalar elde edilmiştir.

İki belge üzerinde yapılan incelemeye göre ortak temalardan birinin, öğreneni merkeze alan, öğrenci odakl1 yaklaşım olduğu görülmektedir. Dewey'nin raporunda (1924: 3) geçen "talebenin teşebbüs kabiliyetini ve faaliyetini teşvik ettiği bittecrübe sabit olan tedrisat usulleri” eğitim etkinliklerinin öğrencinin yeteneklerini geliştirici ve bizzat kendisinin yaparak yaşayarak öğrenmesine ilişkindir. MEB 2023 Vizyonu Belgesi'nde (2018: 14) "Eğitimin ana ögesi ve baş öznesi insandır" denilmektedir. Ayrica MEB 2023 Vizyonu Belgesi'nde (2018: 21) "Öğrenme, öğrenen bireyin öz sorumlulugŭ ve tatminiyle ilgilidir." ifadesiyle de öğrenci odaklı eğitim vurgulanmaktadır. "Yaparak ve yaşayarak öğrenme" teması, Dewey'nin raporunda, okulların daha yapım aşamalarından öğrenme ortamlarına uygun şekilde düzenlenmesi şeklinde önerilmektedir (Dewey, 1924: 11). MEB 2023 Eğitim Vizyonu Belgesi'nde (2018: 25) ise "İçerik ve Uygulama" başlığında "Tasarım-Beceri Atölyeleri" kurulması hedeflenerek öğrencilerin becerilerinin geliştirilmesi öncelikli hale getirilmektedir. Yine her iki belgede öğretmenin öğrenciyle etkileşimine özel bir önem verilmiştir. Dewey'nin raporunda öğretmenlerin sadece bilgi aktaran durumunda değil, bulundukları yerlerde sağlık, tarım ve hayvancılık gibi alanlarda yol gösterici olma durumundan bahsedilmiştir (Dewey, 1924: 9-10). MEB 2023 Eğitim Vizyonu Belgesi'nde (2018: 21) "Birlikte yapılan bu yolculukta ana aktör öğretmendir." denilerek öğretmen sistemin odağına oturtulmuştur. 
Araştırmada incelenen iki belgede de vurgulanan ve desteklenen temalar benzerlik göstermektedir. Fakat, bulundukları dönemin ekosistemi içerisinde söylediklerini şekillendirmektedirler. Dewey'nin (1924) raporunda temel eğitim ve kırsal hayattaki eğitimle bütünleşmiş bir model ön plana çıkmaktadır. Buna karşın, MEB 2023 Eğitim Vizyonu Belgesi'nde (2018) ise 21. yüzyılın olmazsa olmazı teknolojiyi ve eğitimi bütünleştirmek dikkat çekmektedir. Çünkü MEB 2023 Eğitim Vizyonu Belgesi (2018), Dewey'nin (1924) hazırladığı raporda işaret edilen "yaparak, yaşayarak öğrenme" ve de "öğrenci odaklı yaklaşıma" ilişkin ihtiyacın günümüz dijital çağdaki yansımasına işaret etmektedir. Buna bağlı olarak, eğitim program ve süreçlerinin dijitalleşme ve öğrenen odaklı bir yönlendirmeyle yeniden yapılandırılması gerekmektedir.

$\mathrm{Bu}$ araştırmanın her iki belgedeki benzerliklere dair sonuçları, Dewey’nin eğitim felsefesinin öğrenci odaklı yaklaşımda ve öğrenci ihtiyaçlarına odaklı eğitim anlayışındaki önemini göstermektedir. Eğitimin geleceği açısından baktığımızda, Türk eğitim sisteminde Dewey'nin etkisinin resmi belgelerde halen sürdüğü söylenebilir. Eğitim politikalarına yön veren yöneticilerin "öğrenci ve öğretmeni eğitimin öznesi” olarak kabul eden uygulamalar geliştirmesi beklenmektedir.

Öte yandan, Dewey'nin Amerikan asıllı bir eğitimci olması sebebiyle "Türkiye Maarifi Hakkında Rapor"unu İngilizce yazmış olduğu düşünülmekle birlikte orijinal metne ulaşılamamıştır. Orijinal metnin arşivlenmesi sağlandığında, uluslararası literatür açısından da cumhuriyetin ilk yıllarındaki eğitim modeliyle ilgilli araştırma yapılması mümkün olacaktır.

Özer'in (2018) araştırmasında, 2023 Eğitim Vizyonu'ndan hareketle mesleki ve teknik eğitim için geliştirilen hedeflerve bu çerçevede son zamanlarda atılan adımlar sunulmaktadır. Araştırmadaki örnekler, kısa sürede gerçekleştirilen eylemleri içermekte olup yeni yol haritasının öngördüğü sektörle birlikte hareket eden ve ülkenin önceliklerine göre kendisini sürekli güncelleyen dinamik bir mesleki eğitim inşası sürecine kısa bir bakış sunmaktadır. Araştırma sonuçlarına göre, kısa sürede yapılanlar göz önüne alındığında ve aynı kararlılıkla devam edildiğinde bu çalışmada belirtilen ana hedeflerin içeriği her geçen gün giderek zenginleşecek ve bu çalışmada değinilmeyen başka olumlu açılımlara da yol açabilecektir. $\mathrm{Bu}$ da mesleki eğitimle ilgili yıllardan beri dile getirilen eleştirilerin ortadan kalkmasına yol açacak ve mesleki eğitimden beklentilerin karşılanmasını sağlayacaktır.

Öte yandan, Baltacı ve Coşkun (2019) yaptıkları çalışmada öğretmenlerin 2023 Eğitim Vizyonu Belgesine ilişkin algılarını belirlemeyi amaçlamışlardır. $\mathrm{Bu}$ araştırma ile öğretmenlerin 2023 eğitim vizyonuna ilişkin düşük düzeyde bir algılarının olduğu belirlenmiştir. $\mathrm{Bu}$ durum öğretmenlerin benimsemedikleri bir eğitim felsefesini, uygulamada zorlanacakları ve söz konusu vizyonun gerçekleşmesinin zorlaşacağı anlamına gelmektedir. Ayrıca öğretmenler kendilerini bu denli vizyoner bir politika belgesi karşısında yetersiz hissetmekte ve belgenin hedeflerini de benimsememektedirler.

Ertürk'ün (2020) çalışmasında, Milli Eğitim Bakanlığı tarafindan yayınlanan 2023 Eğitim Vizyonu Belgesi, Türk Eğitim Sistemi'nde bulunan ve eğitim yönetimi alanı ile ilgili olan sorunlar çerçevesinde incelenmiş ve araştırmada elde edilen bulgularda vizyon belgesinde eğitim yönetimi alanında olumlu yönde yeniliklerin planlandığ saptanmıştır. Ancak yapılması planlanan bu yeniliklerin var olan ve adım atılması beklenen sorunların çözümü noktasında yeterli olmadığı görülmüştür.

Yapılan bu çalışmaların 1şı̆̆ında, MEB 2023 Eğitim Vizyonu Belgesi'nin (2018) kuramda var olan sorunlara değindiği ve çözüm önerileri ürettiği, fakat yeni olması nedeniyle uygulamada sorunlar çıktığı görülmektedir. $\mathrm{Bu}$ sebeple, MEB 2023 Eğitim Vizyonu Belgesi'nin (2018) hem uygulamaları hem de bu uygulamaların yansımaları açısından önümüzdeki yıllarda detaylı biçimde araştırılmasının dikkat çekici sonuçlar ortaya koyabileceği düşünülmektedir. Eğitime farklı bir felsefi bakış açısı getirmesi ve eğitim kurumunda yıllardır beklenen sorunların çözümü için bir umut 1şığı doğurması açısından MEB 2023 Eğitim Vizyonu Belgesi'nin Türk eğitim sistemi politikasının şekillenmesinde önemli rol oynayacağı açıktır. Ancak eğitim felsefelerinde yapılan değişikliklere eğitim paydaşlarının uyumu zaman alacağından, dönüşümden istenen verimin en az birkaç kuşak sonra alınabileceği unutulmamalı, gelecekte yapılacak araştırmalar bu yönde şekillendirilmelidir.

$\mathrm{Bu}$ araştırma literatürde henüz yeterince ele alınmayan bir konuya yönelmiş ve Dewey’nin Türk Marifi Hakkındaki Rapor'u ile MEB 2023 Eğitim Vizyonu Belgesi'nde kullanılan temaların benzerlik ve farklılıkları ortaya koymaya çalışmıştır. İlerleyen dönemlerde, MEB 2023 Eğitim Vizyonu Belgesi'nde konulan hedeflere ulaşma düzeyi yeni bir araştırma konusu olabilir. Ayrıca, hem nitel hem nicel araştırmalar hem de karma yöntem yolu ile eğitim paydaşlarının MEB 2023 Eğitim Vizyonu Belgesi'ne ilişkin algıları belirlenip, süreç boyunca, olumsuz algılara ilişkin iyileştirmeler yapılabilir. Öte yandan, MEB 2023 Eğitim Vizyonu Belgesi ile geçmiş yıllarda yayınlanan vizyon belgeleri veya eğitim raporları arasındaki ortak temalar belirlenip, bu temaların başarılma düzeyleri başka bir araştırmanın konusu olabilir. Ayrıca, dijital çağın yeterliliklerine ilişkin hedefler koyan MEB 2023 Eğitim Vizyonu Belgesi'ne yönelik kapsamlı bir tanıtım programı hazırlanmasının, belgenin öğretmenler dahil tüm paydaşlar tarafindan benimsemesine katkı sağlayacağ düşünülmektedir.

\section{Kaynakça}

Balım, A. G., Inel, D., \& Evrekli, E. (2008). The effects of the using of concept cartoons in science education on students' academic achievements and enquiry learning 
skill perceptions. Elementary Education Online, 7(1), 188-202.

Baltacı, A., \& Coşkun, M. K. (2019). Teacher perceptions regarding the 2023 educational vision. HAYEF: Journal of Education, 16(2), 130-155.

Bender, M. T. (2005). John Dewey'nin eğitime bakışı üzerine yeni bir yorum. Gazi Üniversitesi Kırşehir Ĕ̈itim Fakültesi Dergisi, 6(1), 13-19.

Bowen, G. A. (2009). Document analysis as a qualitative research method. Qualitative Research Journal, 9(2), 27-40. doi:10.3316/QRJ0902027

Bülbül, M. (2009). 2000’li yılların eğitim problemlerine 1920'lerden çözüm önerileri: Dewey'den bugüne ne değişti?. Türk Eğitim Bilimleri Dergisi, 7(3), 667-689.

Dewey, J. (1924). Türkiye maarifi hakkında rapor. 11 Mart 2019 tarihinde https://acikerisim.tbmm.gov.tr/handle/11543/928 adresinden erişildi.

Dewey, J. (1997). Experience and education. New York, Touchstone Bcck.

Düşkün, Y., Arık, B. M., \& Aydagül, B. (2018). Vizyon belgesi neler getiriyor ve nasıl güçlendirilebilir?

10 Kasım 2019 tarihinde

https://www.egitimreformugirisimi.org/vizyon-belgesineler-getiriyor-ve-nasil-guclendirilebilir/ adresinden erişildi.

Efendioğlu, A., Berkant, H. G., \& Arslantaş, Ö. (2010, Mayıs). John Dewey'nin Türkiye maarifi hakkında raporu ve Türk eğitim sistemi (Öz). 1. Ulusal Eğitim Programları ve Öğretim Kongresi'nde sunulan bildiri, Balıkesir Üniversitesi, Balıkesir. 10 Kasım 2019 tarihinde https://www.researchgate.net/publication/311424798 adresinden erişildi.

Elçiçek, Z. \& Han, B. (2018). Evaluation of 2023 education vision. Inesec International Social Sciences and Education Conference, 1, 250.

Ertürk, A. (2020). 2023 Eğitim Vizyonu: Sorunlara çare mi? Pamukkale Üniversitesi Ë̈itim Fakültesi Dergisi, 48, 321-345. doi: 10.9779/pauefd.537273
Lorsbach, A. W., \& Tobin, K. (1992). Constructivism as a referent for science teaching. 5 Kasim 2019 tarihinde http://my.ilstu.edu/ awlorsb/referent.pdf adresinden erişildi.

Kepes, G. (2018). Education of Vision. New York: Sage.

Kösterelioğlu, İ., \& Bayar, A. (2014). Türk eğitim

sisteminin sorunlarına ilişkin güncel bir değerlendirme, International Journal of Social Science, 25(1), 177187.

Milli Eğitim Bakanlığı (2018). 2023 Eğitim vizyonu.

Erişim Adresi: 11 Mart 2019 tarihinde http://2023vizyonu.meb.gov.tr/doc/2023_EGITIM_VI ZYONU.pdfadresinden erişildi.

Mutlu, M. (2008). Eğitim fakültesi öğrencilerinin öğrenme stilleri. Atatürk Üniversitesi Kazım Karabekir Ĕgitim Fakültesi Dergisi, 17, 1-21.

O'Leary, Z. (2014). The essential guide to doing your research project (2nd ed.). Thousand Oaks, CA: SAGE Publications, Inc. 11 Mart 2019 tarihinde https://1led500.trubox.ca/2016/244 adresinden erişildi.

Özer, M. (2018). 2023 Eğitim vizyonu ve mesleki ve teknik eğitimde yeni hedefler. Yükseköğretim ve Bilim Dergisi/Journal of Higher Education and Science, $8(3), 425-435$.

Saylan, N., \& Çiftçioğlu R. (Ekim, 2011). John Dewey ve program geliştirme (Öz). 1. Uluslararası Eğitim Programları ve Öğretim Kongresi'nde sunulan bildiri, Anadolu Üniversitesi, Eskişehir. 5 Şubat 2019 tarihinde

https://www.pegem.net/Akademi/kongrebildiri_detay. aspx ?id=127503 adresinden erişildi.

Selvi, K., Sönmez, B., \& Özüdoğru, F. (2014). John Dewey: Okul, toplum ve eğitim. Anadolu Üniversitesi Sosyal Bilimler Dergisi, 14 (Eğitim Özel Sayı), 25-34.

Silverman, D. (2014). Interpreting qualitative data. Sage Publications Ltd.

Şener, G. (2018). Türkiye'de yaşanan eğitim sorunlarına güncel bir bakış. Milli Eğitim Dergisi, 47(218), 187200.

Yıldırım, A., \& Şimșek, H. (2006). Sosyal bilimlerde nitel araştırma yöntemleri. Ankara: Seçkin Yayınevi. 


\section{EKLER}

Tablo 2. Dewey'nin Türkiye Maarifi Hakkındaki Raporundaki Kodlar ve Temalar

\begin{tabular}{|c|c|c|c|c|c|}
\hline \multirow[t]{2}{*}{ Temalar } & \multirow[t]{2}{*}{ Kodlar } & \multicolumn{2}{|c|}{$\begin{array}{l}\text { Kodlar Toplamı } \\
(\mathrm{N})\end{array}$} & \multirow{2}{*}{$\begin{array}{l}\text { Gözlenen Kod } \\
\text { Toplamı } \\
\mathrm{f} \sum\end{array}$} & \multirow{2}{*}{ 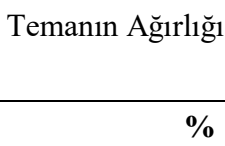 } \\
\hline & & f & $\%$ & & \\
\hline \multirow[t]{4}{*}{$\begin{array}{l}\text { Yaparak yaşayarak } \\
\text { ögrenme }\end{array}$} & $\begin{array}{l}\text { Öğrencinin yeteneğinin } \\
\text { keşfedilmesi }\end{array}$ & 28 & 32 & \multirow{4}{*}{88} & \multirow{4}{*}{9} \\
\hline & $\begin{array}{l}\text { Ders içeriklerine uygun } \\
\text { malzemelerle deneyerek eğitim }\end{array}$ & 18 & 11 & & \\
\hline & $\begin{array}{l}\text { Köy hayatında gerekli bilgi } \\
\text { becerilerin edinilmesi }\end{array}$ & 26 & 30 & & \\
\hline & $\begin{array}{l}\text { Meslek alanlarında ilgili atölye } \\
\text { ve yerlerde stajların yürütülmesi }\end{array}$ & 16 & 18 & & \\
\hline \multirow[t]{3}{*}{ Öğretmen Yetiştirme } & $\begin{array}{l}\text { Meslektaşlar arasında bilgilerin } \\
\text { paylaşımı }\end{array}$ & 14 & 22 & \multirow{3}{*}{64} & \multirow{3}{*}{7} \\
\hline & $\begin{array}{l}\text { Öğretmenlerin hizmetiçi eğitim } \\
\text { için yurt dişına gönderilmesi }\end{array}$ & 36 & 56 & & \\
\hline & $\begin{array}{l}\text { Meslektaşlar arasında bilgilerin } \\
\text { paylaşımı }\end{array}$ & 14 & 22 & & \\
\hline \multirow[t]{2}{*}{$\begin{array}{l}\text { Öğrenci Merkezli } \\
\text { Eğitim }\end{array}$} & $\begin{array}{l}\text { Öğrencilerin gereksinim ve } \\
\text { ihtiyaçlarına göre eğitim } \\
\text { sürecinin planlaması }\end{array}$ & 22 & 44 & \multirow{2}{*}{50} & \multirow[t]{2}{*}{5} \\
\hline & $\begin{array}{l}\text { Öğrencilerin farklı alanlara } \\
\text { yönlendirilmesi }\end{array}$ & 28 & 56 & & \\
\hline \multirow[t]{4}{*}{ Köy Hayat1 } & $\begin{array}{l}\text { Ders programlarının bununla } \\
\text { uyumlu hale getirilmesi }\end{array}$ & 18 & 29 & \multirow{4}{*}{62} & \multirow{4}{*}{6} \\
\hline & $\begin{array}{l}\text { Okulların halkın eğitim merkezi } \\
\text { olması }\end{array}$ & 21 & 34 & & \\
\hline & $\begin{array}{l}\text { Okulların öğrenciler aracılığıyla } \\
\text { bilgi toplama merkezi olması }\end{array}$ & 7 & 11 & & \\
\hline & $\begin{array}{l}\text { Köy hayatındaki ihtiyaçlara } \\
\text { uygun yetişkin eğitimleri de } \\
\text { yapılması }\end{array}$ & 16 & 26 & & \\
\hline \multirow{4}{*}{$\begin{array}{l}\text { Öğretmenin ekonomik } \\
\text { şartlarının } \\
\text { iyileştirilmesi }\end{array}$} & Maaşların yeniden ele alınması & 8 & 19 & \multirow{4}{*}{42} & \multirow{4}{*}{4} \\
\hline & $\begin{array}{l}\text { Mesleğin ekonomik şartları } \\
\text { düzenlenerek özendirilmesi }\end{array}$ & 12 & 29 & & \\
\hline & $\begin{array}{l}\text { Geçim sıkıntısı çekmelerinin } \\
\text { engellenmesi }\end{array}$ & 16 & 38 & & \\
\hline & Lojman inşaatlarının yapımı & 6 & 14 & & \\
\hline \multirow[t]{3}{*}{ Bütçe } & $\begin{array}{l}\text { Okul yapımı için bütçenin doğru } \\
\text { kullanılması }\end{array}$ & 12 & 26 & \multirow{3}{*}{47} & \multirow{3}{*}{5} \\
\hline & $\begin{array}{l}\text { Milli Eğitim Teşkilatına gerekli } \\
\text { bütçelendirmenin yapılması }\end{array}$ & 14 & 30 & & \\
\hline & $\begin{array}{l}\text { Öğretmen maaşlarının gözden } \\
\text { geçirilmesi }\end{array}$ & 8 & 17 & & \\
\hline \multirow[t]{2}{*}{ Ödenek } & $\begin{array}{l}\text { Okul yapımı için ödenek } \\
\text { oluşturulması }\end{array}$ & 12 & 43 & \multirow[b]{2}{*}{28} & \multirow[b]{2}{*}{3} \\
\hline & $\begin{array}{l}\text { Öğretmen ve öğretmen } \\
\text { yetiştiriciler için ödenek } \\
\text { ayrılması }\end{array}$ & 16 & 57 & & \\
\hline \multirow[t]{3}{*}{ Tarım/Ziraat } & Tarıma önem verilmesi & 26 & 40,6 & \multirow{3}{*}{64} & \multirow{3}{*}{6} \\
\hline & $\begin{array}{l}\text { Tarım ve sanayi okullarının } \\
\text { açılması }\end{array}$ & 16 & 25 & & \\
\hline & Çiftçilerin eğitilmesi & 22 & 34,4 & & \\
\hline \multirow[t]{2}{*}{ Ders Programları } & $\begin{array}{l}\text { Yerel ihtiyaçlara göre derslerin } \\
\text { düzenlenmesi }\end{array}$ & 18 & 32,2 & 56 & 6 \\
\hline & $\begin{array}{l}\text { Tarım ve hayvancılık gibi köy } \\
\text { hayatına yönelik eğitimlerin de } \\
\text { verilmesi }\end{array}$ & 14 & 25 & & \\
\hline
\end{tabular}




\begin{tabular}{|c|c|c|c|c|c|}
\hline & $\begin{array}{l}\text { Okulların ders içerikleriyle } \\
\text { uyumlu olarak kademeleştiril- } \\
\text { mesi }\end{array}$ & 24 & 42,8 & & \\
\hline \multirow[t]{4}{*}{ Kütüphanecilik } & Seyyar Kütüphane kurulmas1 & 9 & 10 & \multirow{4}{*}{91} & \multirow{4}{*}{9} \\
\hline & Kitapları halka ulaştırılması & 24 & 26 & & \\
\hline & $\begin{array}{l}\text { Okullarda kütüphaneler } \\
\text { oluşturulması }\end{array}$ & 26 & 29 & & \\
\hline & $\begin{array}{l}\text { Okul kütüphanelerinin halka } \\
\text { açılması }\end{array}$ & 32 & 35 & & \\
\hline \multirow[t]{3}{*}{ Okuma-yazma } & $\begin{array}{l}\text { Okullarda yetişkinlere de } \\
\text { okuma-yazma eğitiminin } \\
\text { verilmesi }\end{array}$ & 16 & 20 & \multirow{3}{*}{80} & \multirow{3}{*}{8} \\
\hline & & & & & \\
\hline & $\begin{array}{l}\text { Halk arasındaki okuma-yazma } \\
\text { oranın artırılması }\end{array}$ & 38 & 47,5 & & \\
\hline Okuma alışkanlığı & $\begin{array}{l}\text { Halkın kitaplara erişiminin } \\
\text { arttırılması }\end{array}$ & 26 & 100 & 26 & 3 \\
\hline \multirow[t]{3}{*}{ Yaşamboyu Eğitim } & $\begin{array}{l}\text { Hayata dair becerilere yer } \\
\text { verilmesi }\end{array}$ & 34 & 42,5 & \multirow{3}{*}{80} & \multirow{3}{*}{8} \\
\hline & $\begin{array}{l}\text { Öğretmenlere çeşitli hizmetiçi } \\
\text { eğitimler sunulması }\end{array}$ & 28 & 35 & & \\
\hline & $\begin{array}{l}\text { Sağlıklı yaşamla ilgili } \\
\text { becerilerin kazandırılması }\end{array}$ & 18 & 22,5 & & \\
\hline \multirow[t]{9}{*}{$\begin{array}{l}\text { MEB'in merkeziyetçi } \\
\text { yapıs1 }\end{array}$} & $\begin{array}{l}\text { Öğretmenlere yardımcı olacak } \\
\text { kaynak eserlerin merkezi } \\
\text { teşkilatça sağlanması }\end{array}$ & 24 & 10 & \multirow{9}{*}{246} & \multirow{9}{*}{24} \\
\hline & $\begin{array}{l}\text { Okul binaları için gerekli } \\
\text { ölçütler belirlenmesi }\end{array}$ & 18 & 7 & & \\
\hline & Öğrenci sayısının belirlenmesi & 32 & 13 & & \\
\hline & $\begin{array}{l}\text { Öğretmen ihtiyacının } \\
\text { belirlenmesi }\end{array}$ & 16 & 7 & & \\
\hline & Merkeziyetçi yap1 kurulması & 28 & 11 & & \\
\hline & $\begin{array}{l}\text { Yerelliklere de yeterince yer } \\
\text { açılması }\end{array}$ & 36 & 15 & & \\
\hline & $\begin{array}{l}\text { Okulların rehber ve yol } \\
\text { göstericilik rolü üstlenmesi }\end{array}$ & 32 & 13 & & \\
\hline & $\begin{array}{l}\text { Okulların yerel koşullara göre } \\
\text { esneklik sağlanması }\end{array}$ & 28 & 11 & & \\
\hline & Denetimlerin yap1lmas1 & 32 & 13 & & \\
\hline \multirow[t]{4}{*}{ Okul Yöneticiliği } & $\begin{array}{l}\text { Yöneticilerin öğretmen } \\
\text { okullarında yetiştirilmesi }\end{array}$ & 22 & 30 & \multirow{4}{*}{74} & \multirow{4}{*}{7} \\
\hline & $\begin{array}{l}\text { Yöneticilerin bürokratik } \\
\text { süreçlerden kurtulması }\end{array}$ & 16 & 22 & & \\
\hline & $\begin{array}{l}\text { Karar süreçlerinin } \\
\text { paylaş1lması }\end{array}$ & 12 & 16 & & \\
\hline & $\begin{array}{l}\text { Yöneticilerin öğretmen } \\
\text { okullarında yetiştirilmesi }\end{array}$ & 24 & 32 & & \\
\hline
\end{tabular}


Tablo 3. MEB 2023 Eğitim Vizyonu Belgesindeki Kodlar ve Temalar

\begin{tabular}{|c|c|c|c|c|c|}
\hline \multirow[t]{2}{*}{ Temalar } & \multirow[t]{2}{*}{ Kodlar } & \multicolumn{2}{|c|}{ Kodlar Toplamı } & $\begin{array}{l}\text { Gözlenen Kod } \\
\text { Toplamı }\end{array}$ & Temanın Ağırlığı \\
\hline & & $\mathrm{f}$ & $\%$ & $\mathrm{f} \sum$ & $\%$ \\
\hline \multirow[t]{4}{*}{$\begin{array}{l}\text { Yaparak yaşayarak } \\
\text { öğrenme }\end{array}$} & $\begin{array}{l}\text { Öğrencinin yeteneğinin } \\
\text { keşfedilme-si }\end{array}$ & 24 & 20 & \multirow{4}{*}{118} & \multirow{4}{*}{14} \\
\hline & $\begin{array}{l}\text { Doğal öğrenme } \\
\text { sisteminin kullanılma-s1 }\end{array}$ & 16 & 14 & & \\
\hline & $\begin{array}{l}\text { Bilginin beceriye } \\
\text { dönüştürül-mesi }\end{array}$ & 64 & 54 & & \\
\hline & $\begin{array}{l}\text { Öğrencilere yetkinlik } \\
\text { kazandırıl-ması }\end{array}$ & 14 & 12 & & \\
\hline \multirow[t]{4}{*}{$\begin{array}{l}\text { Bireysel potansiyelin } \\
\text { gerçekleştiril-mesi }\end{array}$} & $\begin{array}{l}\text { Eğitimin merkezinde } \\
\text { insan olmalı }\end{array}$ & 68 & 52 & \multirow{4}{*}{130} & \multirow{4}{*}{15} \\
\hline & $\begin{array}{l}\text { Bireysel farklılıkların } \\
\text { dikkate alınması }\end{array}$ & 32 & 25 & & \\
\hline & $\begin{array}{l}\text { Bireyin kendini } \\
\text { tanımasının sağlanması }\end{array}$ & 12 & 9 & & \\
\hline & $\begin{array}{l}\text { Bireylerin } \\
\text { yaratıcılığının da } \\
\text { bilginin oluşumun-da } \\
\text { kullanıl-ması }\end{array}$ & 18 & 14 & & \\
\hline \multirow[t]{3}{*}{ Öğrenci odaklı eğitim } & $\begin{array}{l}\text { Öğrencinin çok boyutlu } \\
\text { olarak değerlendi- } \\
\text { rilmesi }\end{array}$ & 22 & 37 & \multirow{3}{*}{59} & \multirow{3}{*}{7} \\
\hline & $\begin{array}{l}\text { Programın öğrenciye } \\
\text { uygun hale getirilmesi }\end{array}$ & 23 & 39 & & \\
\hline & $\begin{array}{l}\text { Öğrenci eğitimin öznesi } \\
\text { olmas1 }\end{array}$ & 14 & 24 & & \\
\hline \multirow[t]{3}{*}{$\begin{array}{l}\text { Düşünme becerilerinin } \\
\text { geliştiril-mesi }\end{array}$} & $\begin{array}{l}\text { Sorun çözme becerisinin } \\
\text { geliştirilmesi }\end{array}$ & 14 & 47 & \multirow{3}{*}{30} & \multirow{3}{*}{3} \\
\hline & $\begin{array}{l}\text { Eleştirel düşünmenin } \\
\text { kazandırılması }\end{array}$ & 12 & 40 & & \\
\hline & $\begin{array}{l}\text { Yumuşak becerileri öne } \\
\text { çıkaran eğitim anlayışı } \\
\text { kurulması }\end{array}$ & 4 & 13 & & \\
\hline \multirow[t]{2}{*}{$\begin{array}{l}\text { MEB Teşkilatının yeniden } \\
\text { yapılandırıl-ması }\end{array}$} & $\begin{array}{l}\text { Eğitimin sürecinin bütün } \\
\text { olarak (ekosistem gibi) } \\
\text { görülmesi }\end{array}$ & 61 & 70 & \multirow[t]{2}{*}{87} & \multirow[t]{2}{*}{10} \\
\hline & $\begin{array}{l}\text { Okul eğitim sisteminin } \\
\text { merkezinde yer almas }\end{array}$ & 26 & 30 & & \\
\hline \multirow{8}{*}{$\begin{array}{l}\text { Öğretmen yetiştirme ve } \\
\text { öğretmenin güçlendiril- } \\
\text { mesi }\end{array}$} & $\begin{array}{l}\text { Öğretmen niteliğinin } \\
\text { arttırılmas1 }\end{array}$ & 18 & 19 & \multirow{8}{*}{94} & \multirow{8}{*}{11} \\
\hline & $\begin{array}{l}\text { Öğretmen sayısının } \\
\text { artırılması }\end{array}$ & 6 & 6 & & \\
\hline & $\begin{array}{l}\text { Öğretmenin eğitimin } \\
\text { Öznesi olmas1 }\end{array}$ & 4 & 4 & & \\
\hline & $\begin{array}{l}\text { Öğretmenlerin hem yerel } \\
\text { hem de uluslararası } \\
\text { düzeyde niteliklerinin } \\
\text { artırılması }\end{array}$ & 8 & 9 & & \\
\hline & $\begin{array}{l}\text { Aidiyetin } \\
\text { güçlendirilmesi }\end{array}$ & 5 & 5 & & \\
\hline & $\begin{array}{l}\text { Lisansüstü eğitim } \\
\text { düzeyinin hedeflenmesi }\end{array}$ & 15 & 16 & & \\
\hline & $\begin{array}{l}\text { Mesleki gelişim } \\
\text { çalışmalarının } \\
\text { desteklenmesi }\end{array}$ & 24 & 26 & & \\
\hline & $\begin{array}{l}\text { Özlük haklarının yeniden } \\
\text { düzenlenmesi }\end{array}$ & 14 & 15 & & \\
\hline \multirow[t]{3}{*}{ Okul yöneticiliği } & $\begin{array}{l}\text { Okul yöneticiliğin bir } \\
\text { uzmanlık olarak ele } \\
\text { alınması }\end{array}$ & 8 & 6 & \multirow{3}{*}{137} & \multirow{3}{*}{16} \\
\hline & $\begin{array}{l}\text { Okul yöneticilerinin } \\
\text { liderlik özeliklerinin } \\
\text { olması }\end{array}$ & 14 & 10 & & \\
\hline & Okul yöneticilerinin & 14 & 10 & & \\
\hline
\end{tabular}


okullarının ekosistem

koşullarını evrensel

değerlerle

birleştirebilmesi

Eğitimde yer alan tüm

yöneticilerinin

$6 \quad 4$

birbirinden beslenmesi

Yöneticinin olasılıkları

öngörebilme

9

kapasitesinin arttırılması

Okulların gelişimi

üzerine kurulu bir

yönetim anlayışının

58

42

benimsenmesi

Veriye dayalı bir yönetim

anlayışının oturtulması

28

21

\begin{tabular}{|c|c|c|c|c|c|}
\hline \multirow[t]{3}{*}{ Yaşamboyu eğitim } & $\begin{array}{l}\text { Geleceğe yönelik } \\
\text { insanların hazırlanması }\end{array}$ & 12 & 19 & \multirow{3}{*}{64} & \multirow{3}{*}{7} \\
\hline & $\begin{array}{l}\text { Herkes için öğrenmenin } \\
\text { yaşam tarzı haline } \\
\text { gelmesi }\end{array}$ & 38 & 59 & & \\
\hline & $\begin{array}{l}\text { Öğretmenlik mesleğinin } \\
\text { de yaşam boyu eğitim } \\
\text { kapsamında yeniden } \\
\text { değerlendirilme-si }\end{array}$ & 14 & 21 & & \\
\hline \multirow[t]{4}{*}{$\begin{array}{l}\text { Eğitimde dijital } \\
\text { dönüşümün sağlanması }\end{array}$} & $\begin{array}{l}\text { Bilginin yeniden bütünsel } \\
\text { yaklaşımla } \\
\text { yapılandırılması }\end{array}$ & 22 & 15 & \multirow{4}{*}{142} & \multirow{4}{*}{16} \\
\hline & $\begin{array}{l}\text { Eğitimin her boyutunda } \\
\text { dijital dönüşümün } \\
\text { sağlanması }\end{array}$ & 42 & 30 & & \\
\hline & $\begin{array}{l}\text { Disiplinerarası } \\
\text { çalışmalarının } \\
\text { desteklenmesi }\end{array}$ & 16 & 11 & & \\
\hline & $\begin{array}{l}\text { Öğrencilerinin } \\
\text { farklılıklarının dikkate } \\
\text { alınarak dijital araçların } \\
\text { düzenlenmesi }\end{array}$ & 62 & 44 & & \\
\hline
\end{tabular}

